\title{
INOVAR PARA (NÃO) MUDAR: LÍNGUA, ORGANIZAÇÃO INTERNACIONAL, EDUCAÇÃO
}

\section{LUIZA KATIA ANDRADE CASTELLO BRANCO'}

\author{
Programa de Pós-Graduação em Ciências da Linguagem \\ Universidade do Vale do Sapucaí \\ Av. Pref. Tuany Toledo, 470 - 37550-000 - Pouso Alegre - MG - Brasil
}

luizakcbegmail.com

Resumo. Em texto anterior, observamos como o discurso da inovação aparece imbricado ao do empreendedorismo, e demos visibilidade ao funcionamento da forma material "inovação" como um pré-construído, que, em seu processo de produção de sentido apontou para o campo do econômico/financeiro. Refletimos, ainda, sobre o modo discursivo de pensar e realizar inovação na academia, a partir do projeto de uma enciclopédia e da construção de um arquivo. No texto para essa revista, buscamos compreender como o discurso "sobre" e "da" inovação atravessa/sustenta o da educação. Nossos gestos de análise vão na direção de mostrar como as discursividades produzidas por organizações internacionais (formahistórica espaço de direito, BRANCO, 2013) - tais como a UNESCO (United Nations Educational, Scientific and Cultural Organization) - se sustentam no discurso da 'inovação empreendedora' e comparecem nos documentos por elas produzidos, apontando para um vínculo com exigências socioeconômicas, muitas das quais impostas pelo mercado externo; $e$ (re)produzem efeitos de sentido para inovação, produção de conhecimento e educação que se circunscrevem à nova ordem política da globalização que reconhece como crescente o poder das organizações supranacionais que ajudam a definir uma nova forma de produção global, com seus regimes de exploração e controle característicos dessa ordem mundial contemporânea (HARDT; NEGRI, 2010). Ou seja, desconhecendo a linguagem como prática de sentidos inscrita na história, e ignorando um modo de refletir sobre Educação que considera, entre outras coisas, a abertura e a opacidade da história e do simbólico (ORLANDI).

Palavras-chave: língua, organização internacional, educação, inovação.

\begin{abstract}
In a previous text, we observed how the discourse of innovation appears linked to that of entrepreneurship. At that time we showed the functioning of the material form "innovation" as a pre-built, which in its production of meaning process pointed to the field of Economics / Finance. We also reflect on the discursive way of thinking and performing innovation in the university, from the design of an encyclopedia and the construction of a discursive archive. In the text for this journal, we seek to understand how the discourse "about" and "of" innovation crosses / sustains that one of education. Our gestures of analysis aim at the way the discursiveness
\end{abstract}

\footnotetext{
${ }^{1}$ Docente no Programa de Pós-graduação em Ciências da Linguagem, da Universidade do Vale do Sapucaí.
} 
produced by international organizations (form-historical space of law, BRANCO, 2013) - such as UNESCO (United Nations Educational, Scientific and Cultural Organization) - sustains/crosses 'entrepreneurial innovation' discourse and appear in the documents produced by them, pointing to a link with socioeconomic requirements, many of which are imposed by the external market. We also analyze how this discursiveness (re)produces meaning effects for innovation, production of knowledge and education that are confined to the new political order of globalization that recognizes as growing the power of supranational organizations that help to define a new form of global production with its exploitation and control regimes in this contemporary world order (HARDT; NEGRI, 2010). That is, ignoring language as a practice of meaning inscribed in history, and ignoring a way of reflecting on Education that considers, among other things, the openness and opacity of history and symbolic (ORLANDI).

Keywords: language, international organization, education, innovation.

O que sempre me atraiu, me seduziu na Análise de Discurso é que ela ensina a pensar, é que ela nos tira as certezas e o mundo fica mais amplo, menos sabido, mais desafiador. [...] para compreender é preciso teorizar.

(ORLANDI, E. Entrevista à Revista Teias)

E não devemos constatar, ainda uma vez, que só nos aventuramos nessas regiões [a dos fatos de sentidos] porque não podemos nos desviar delas, por razões que, paralelamente, não vêm sem riscos pessoais para aqueles que as habitam?

(HENRY, P. Sentido, sujeito, origem)

Para esse texto ${ }^{2}$, insistimos ainda no que nos inquietou durante nosso pósdoutorado $^{3}$, a saber, o funcionamento da forma material inovação. Durante esse estágio, um arquivo se pôs em construção a partir da dispersão dos textos que nos des/en-viavam em nosso movimento de leitura. Após várias idas e vindas, ainda agora, podemos observar o modo como os efeitos de sentido produzidos no discurso "sobre" e "da" inovação se atravessa(ra)m e se sustenta(ra)m por/em outros discursos, como o do empreendedorismo, o da economia, o da ciência, o da sustentabilidade, o do administrativo, o do jurídico, e outros. Em texto anterior ${ }^{4}$, pudemos observar funcionamentos dessa forma "inovação"

\footnotetext{
${ }^{2} \mathrm{O}$ que aqui escrevemos baseia-se no texto da conferência proferida na Universidade do Vale do Sapucaí (UNIVÁS - Programa de Pós-Graduação em Ciências da Linguagem), em 22 de junho de 2017, a convite do Prof. Dr. Eduardo Alves Rodrigues.

${ }^{3}$ Pós-Doutorado realizado no Programa de Pós-Graduação em Estudos de Linguagem sob supervisão da Prof $^{a}$ Dr $^{a}$ Bethania Mariani, com financiamento PNPD-CAPES (2015-2017).

4 Texto publicado como capítulo no e-book Enciclopédia audiovisual virtual de termos, conceitos $e$ pesquisas em Análise do Discurso e áreas afins: investigação, inovação, divulgação, organizado por
} 
como um pré-construído - um saber construído alhures que funciona como um 'semprejá-lá' no âmbito da formulação, isto é, como uma evidência -, num movimento de paráfrase, produzindo efeitos de sentidos que circulavam apontando, dominantemente, para o campo do econômico/financeiro. Ainda, ali, refletimos sobre como o modo discursivo de pensar e realizar o projeto de uma enciclopédia e a construção de um arquivo na Academia fazem deslizar os sentidos estabilizados de inovação, apontando para o não-um do sentido; inovar, discursivamente, não é sem o político e o ideológico que nos constituem; desloca-se do produto para o processo, do senso comum para o questionamento. No texto para essa revista, buscamos compreender como o discurso "sobre" e "da" inovação atravessa/sustenta/(re)diz o da educação. Nossos gestos de análise vão na direção de mostrar como as discursividades produzidas por organizações internacionais (forma-histórica espaço de direito, BRANCO, 2013) - tais como a UNESCO (United Nations Educational, Scientific and Cultural Organization) - se sustentam no discurso da 'inovação empreendedora' e comparecem nos documentos por elas produzidos, apontando para um vínculo com exigências socioeconômicas, muitas das quais impostas pelo mercado externo. A lógica parece ser: inovação e conhecimento são indissociáveis; inovação e produção de conhecimento estão inexoravelmente unidos à educação; as organizações internacionais como a UNESCO têm a missão (meta e estratégia explícitas) de promover a inovação educacional nos espaços de seus Estadosmembros buscando a mudança e a modernização. Essas discursividades buscam hegemonizar efeitos de sentido para inovação, produção de conhecimento e educação que se circunscrevem à 'nova' ordem política da globalização (HARDT; NEGRI, 2010): ativa e em expansão, uma 'nova' ordem universal que não aceita limites; ordem que traz uma mudança radical às noções de soberania, nação e povo, e que reconhece como crescente o poder das organizações supranacionais que 'ajudam' a definir uma 'nova' forma de produção global, com seus regimes de exploração e controle característicos dessa ordem mundial contemporânea. Discursivamente falando, uma ordem que desconhece a linguagem como prática de sentidos inscrita na história, e ignora um modo de refletir sobre os sentidos de educação que considera, entre outras coisas, a abertura e a opacidade da história e do simbólico. Essas discursividades sobre a relação inovação/educação caminha pari passu com a lógica da inovação conforme definida por Schumpeter ([1942] 2003, p. 5), como um processo de "destruição criadora" fundamental para a existência do capitalismo, pois "todo empreendimento capitalista deve, quer queira, quer não, adaptarse ao novo". Todavia, somos advertidos sobre o discurso sobre o novo, do que se coloca como atual, diferente, "novo", aquele que atualiza redes de memória parecendo produzir uma memória outra, sentidos outros: o discurso que "aproveita fragmentos do ritual já instalado - da ideologia significante, apoiando-se em retalhos dele para instalar o novo" (ORLANDI, 2003b, p. 13).

Dividimos nosso artigo em quatro partes. Uma primeira em que exploramos teoricamente o modo como a noção de espaço é fundamental para pensar a relação sujeito/língua e em que formulamos sobre a organização internacional como forma histórica espaço de direito e suas consequências teóricas para essa relação. Uma segunda e terceira partes em que refletimos discursivamente sobre o referente discursivo inovação, a partir de recortes e de sequências discursivas, observando o funcionamento da forma material 'inovação', textualizada em definições, por exemplo, e também apresentando uma reflexão sobre o discurso da inovação como constitutivo da forma histórica

Mariani (2016). Disponível para download em http://www.edicoesmakunaima.com.br/catalogo/5enciclopedia/22-enciclopedia-virtual-ad-investigacao-inovacao-divulgacao. 
capitalista de ser sujeito de e sujeito a, ocasião em que damos visibilidade a dizeres que parecem produzir o atravessamento/intersustentação entre os discursos da inovação e da educação, em documentos e notícias publicados pela UNESCO. E, uma quarta parte, que traz as considerações finnais.

\section{ORGANIZAÇÃO INTERNACIONAL: FORMA HISTÓRICA ESPAÇO DE DIREITO 5}

De nossa parte, queremos pensar a singularidade e a pluralidade não no domínio da cultura, mas na história.

(ORLANDI, Terra à vista)

Pensamos que a questão do espaço requer uma tomada de posição, o que, por sua vez, obriga a pensar as práticas ideológicas, as políticas públicas de língua e uma determinada noção de língua, discursos que trabalham e determinam o funcionamento político do espaço enquanto objeto simbólico. Pensar o espaço como lugar simbólico de produção de sentidos, como também ponto de observação do discursivo, permite refletir sobre as muitas formas materiais simbólicas que o espaço pode compreender e os diferentes sentidos que pode produzir, sendo significado e significando os sujeitos que nele estão e vivem.

Em suas reflexões sobre a materialidade do espaço, Orlandi (2004) toma a cidade como espaço de significação, para compreender o que é espaço urbano e que efeitos de sentido se produzem aí para determinar o que é público. Nesse gesto, ela estabelece uma nova forma de compreender a cidade: pelo discurso, entremeando o sujeito, a história e a língua nessa reflexão. As questões que interessam nesse modo de olhar para a cidade são, por exemplo, como se constituem sujeito e sentido ao funcionarem nesse espaço determinado da cidade, e a forma como esses sentidos, que aí se constituem, se dizem e circulam.

Nessa formulação, Orlandi (2004) observa o modo como o discurso jurídico determina a relação cidade/sujeito dizendo, "a cidade é pensada em relação ao 'droit de cité', introduzindo assim a dimensão jurídica na consideração do cidadão" (id., ibid., p. 11). E, acrescenta, que "uma cidade tem dimensões, formas visíveis, sendo perceptível em primeira instância", o que introduz "a dimensão da representação sensível de suas formas, ao lado da consideração de um espaço de cidadania" (loc. cit.). Desse modo, há uma localização territorial, "cidade e território são solidários", levando à formulação de que o corpo do sujeito está ligado ao corpo da cidade, "de tal modo que o destino de um não se separa do destino do outro", nas mais diversas dimensões, material, histórica, cultural, econômica etc.

No que se refere à nossa reflexão, pensamos que também a nação (o espaço nacional) e as organizações internacionais (o espaço supranacional) podem ser tomadas como espaços de produção de sentidos.

\footnotetext{
${ }^{5}$ Esta seção do texto encontra-se discutida em mais detalhes em BRANCO, 2013.
} 
Ao tomarmos, então, a Organização Internacional como espaço de significação, compreendemo-la como espaço de produção de sentido e de constituição do sujeito pela diversa forma com que a relação sujeito/língua/espaço é afetada pela instituição do jurídico, do administrativo, do social, e do político que individualizam o sujeito na forma histórica espaço de direito ${ }^{6}$ da Organização Internacional.

Consideramos o espaço de uma Organização Internacional como um espaço supranacional, porque, apesar de ser um corpo constituído por nações diversas (os ditos Estados-membros), não é significado como um espaço de encontro atravessado por múltiplos espaços nacionais; é, sim, significado como se fosse um e homogêneo, como um corpo material, concreto, existente em relação ao modo como essa Organização mesma se diz e é dita a partir do jurídico: "um corpo de normas", "sujeito de direito internacional" com "uma capacidade jurídica inerente".

Esse espaço supranacional toma a forma de um sujeito jurídico hegemônico em relação aos outros espaços nacionais, o que silencia o modo político como os sujeitos e línguas em espaço ${ }^{* 7}$ significam seus próprios espaços nacionais de constituição e também o modo como significam esse espaço supranacional. Assim, pensamos que a organização do espaço supranacional sobredetermina os espaços nacionais.

Compreendemos também que essa sobredeterminação não é absoluta, nem completa, porque, se assim o fosse, os espaços nacionais poderiam deixar de existir. Lembremos com Pêcheux: não há ritual sem falha. A ordem do nacional não se apaga nesse discurso do supranacional dito por uma Organização Internacional. Nesse jogo, é interesse da organização que não se apague mesmo, porque há a assimetria econômicofinanceira se imiscuindo nesse processo de dizer sobre as relações entre os espaços nacionais que dividem os sujeitos-membros dessas organizações.

Contudo, há momentos em que é preciso que se apague essa instância da ordem da diversidade das nações, o real das línguas e dos sujeitos em espaços*, para que o discurso da organização (Organização Supranacional e a instância da organização de seu discurso) se instaure de forma hegemônica, atualizando memórias e produzindo evidências como, por exemplo, a da língua 'uma', 'única': 'a' língua portuguesa que 'une' os espaços nacionais múltiplos transformando-os em um, o espaço 'lusófono', sustentando-se para isso nos discursos de/sobre uma etnicidade orientada para um passado e uma história comuns e para um sentido de língua como essência da nação, como veículo dos pensamentos humanos e como conteúdo de todo saber e conhecimento

\footnotetext{
6 Ainda sobre essa noção de espaço como forma histórica conferir Branco (2015) em Línguas e Instrumentos Linguísticos, $\mathrm{n}^{\circ} 36$.

7 "em espaço*" é uma expressão cunhada durante a feitura da tese (BRANCO, 2013) para melhor dizermos de uma língua portuguesa oficial que se singulariza em espaço brasileiro, moçambicano, cabo-verdiano, guineense, santomense, angolano, e, inclusive, português. Essa língua acaba se significando e sendo significada como outras línguas também chamadas de portuguesas. Essas línguas não são a língua portuguesa imaginária nem a língua portuguesa fluida de Portugal (ORLANDI, 2009, 1988); são outras línguas portuguesas (cada uma delas com um funcionamento imaginário e outro fluido), com suas especificidades, memórias e historicidades. Nesse gesto de precisar dizer dessas línguas portuguesas como outras línguas (mas denominadas como 'português' ou 'pretoguês' ou 'língua di terra', por exemplo), pensamos sujeito/espaço como formas históricas de existência, que constituem sentidos e são por eles constituídos. Aqui, no texto, "em espaço*" estaria por outras línguas, que não só as portuguesas, mas que são invisibilizadas, ou, então, hierarquicamente qualificadas como cooficiais, ou, mesmo já, como oficiais, mas com sua singularidade não reconhecida; significadas, hegemonicamente, como 'variantes'.
} 
(HERDER, 2003 [1766]; TÖNNIES, 1979 [1887]). Ou então, por exemplo, produzindo obviedades como a da necessidade do desenvolvimento sustentável, a do empreendedorismo inovador, porque sem isso não há como "impulsionar o progresso mundial na educação" e não há como "contribuir de forma positiva para a economia mundial" (UNESCO, 2014).

É nesse sentido que refletimos sobre o espaço como questão, pensando em sua forma histórica. Buscamos sustentar nossa reflexão pelo que Orlandi (2001, 2002, 2003a, 2004) formula sobre a noção discursiva de sujeito e sentido enquanto relação constitutiva e sobre a noção de espaço enquanto objeto simbólico porque atravessado pela linguagem, constituído de e constituindo sentidos pela/na relação material sujeito/história. E, também, pelo modo como Rodríguez-Alcalá (2011), a partir das formulações de Pêcheux e Orlandi, reflete sobre os sentidos de mundo, dizendo que uma perspectiva discursiva materialista permite dizer desse espaço como simbólico porque permite compreender "o mundo em termos de espaço político e histórico de vida humana, questionando as evidências pelas quais ele se apresenta como espaço natural, independente e anterior aos sujeitos que o habitam e o significam" (id., ibid., p. 244). Nesse mesmo sentido, buscamos aproximar da formulação de sujeito de direito (HAROCHE, 1992) a noção de espaço de direito, tendo em vista o corpo jurídico-administrativo no qual esse Estado-nação e a Organização supranacional se conformam, se significando nesse lugar e interpelando os sujeitos a aí se identificarem e se reconhecerem.

Ajudou-nos nessa reflexão também ler em Lefebvre (1974), no prefácio de seu livro La production de l'espace, o modo como entende o espaço. Não como passivo, vazio, ou, então, como um produto, caso em que seu funcionamento seria o de poder ser trocado, consumido ou de desaparecer. Lefebvre afirma que o espaço intervém na própria produção: na organização do trabalho produtivo, nos transportes, nos fluxos de matériasprimas e de energias. O espaço (em qualquer forma histórica de organização) constitui as relações de produção e as forças produtivas. O conceito de espaço não pode, portanto, ser isolado e permanecer estático. Ele se dialetiza: produto-produtor, suporte de relações econômicas e sociais.

A amplitude das discussões epistemológicas sobre a questão do espaço que encorpam esse texto de Lefebvre se sustenta em bases marxistas, o que o leva a dizer que um determinado modo de produção, dada certa formação social, produz o seu próprio espaço. Isso quer dizer que existe um processo de configuração (ordem e organização) do espaço, de tal modo que ele signifique as condições de produção de que é parte constitutiva e seja significado nelas. O espaço na interpretação de Lefebvre, e isso é fundamental em suas argumentações, é dialético, não apenas produto, mas, outrossim, produtor de relações sociais.

Para Lefebvre, a questão das práticas sociais, as formas pelas quais essas práticas se produzem e organizam determinando espaços e sendo determinadas por eles, tem a ver com a reprodução/transformação da própria formação social, com as relações históricas, ideológicas entre os sujeitos, com a divisão do trabalho, a hierarquização (capitalista) e a consequente forma de ocupação desse espaço.

É também com Guimarães (2005) que dialogamos teoricamente quando pensamos na formulação sobre forma-histórica espaço de direito, porque esse autor pensa o espaço pela linguagem; um espaço simbólico; um espaço com língua e sujeito em relação. Nessa formulação, ele desnaturaliza o sentido de espaço porque não se trata mais do empírico, nem da relação empírica entre sujeito e língua nesse espaço, pois considera a relação entre as línguas e seus falantes constituída por e constituindo um espaço político, regulado e desigual. A partir daí, desenvolve o conceito de espaço de enunciação formulando como 
"espaços de funcionamento de línguas, que se dividem, redividem, se misturam, desfazem, transformam por uma disputa incessante. São espaços 'habitados' por falantes, ou seja, por sujeitos divididos por seus direitos ao dizer e aos modos de dizer" (id., ibid., p. 18).

É necessário pensar os efeitos que a interferência de um espaço supranacional produz nos outros espaços (nacionais e internacionais). Buscamos, assim, explorar essa reflexão sobre espaço/sujeito/língua de modo consequente com a forma como o dispositivo teórico-analítico da Análise de Discurso compreende o trabalho da ideologia e do inconsciente no modo de produção dos sentidos.

É Orlandi (2001) que, ao tratar de espaço urbano público, define espaço, de forma questionadora e instigante, dando a ver que o espaço é objeto simbólico porque atravessado pela linguagem, constituído de e constituindo sentidos pela/na relação material sujeito/história.

Eu fico por aqui, pensando no que é espaço urbano. Esse espaço material concreto funcionando como sítio de significação que requer gestos de interpretação particulares. Um espaço simbólico trabalhado na/pela história, um espaço de sujeitos e de significantes. Não sou indiferente ao que diz P. Henry sobre conceitos como os de dimensão, grandezas, propriedades, experiência. E, como ele, me pergunto, ou nos pergunto, o que sabemos afinal disso que chamamos espaço, este espaço que concebemos como quadro de todos os fenômenos? Que, em nosso caso, seria glosado: o que e como entendemos esse espaço quando se trata do espaço urbano? (ORLANDI, 2001, p. 12)

Compreendemos espaço simbólico ainda conforme Orlandi (2010, p.5), "um espaço de interpretação afetado pelo simbólico e pelo político, dentro da história e da sociedade. Espaço que tem sua materialidade, sua não transparência. Espaço administrado, institucionalizado, organizado, calculado."

Rodríguez-Alcalá (2005), em artigo que discute um dos textos de Pêcheux, retoma a questão relevante do corte simbólico, mostrando que a passagem entre a ordem natural e a ordem humana não se faz nem direta, nem transparente, nem homogeneamente; antes passa pelo simbólico. Ou seja, o espaço não é reflexo do mundo geográfico, natural, porque isso significaria não reconhecer o caráter político, histórico e contingente dos mecanismos que regulam a vida do sujeito numa formação social. É preciso não naturalizarmos a organização político-geográfica do espaço, já que, na perspectiva discursiva, o espaço é concebido como objeto simbólico em sua materialidade e, diríamos mais, em suas formas históricas específicas de significar, o que nos leva a propor, assim, a formulação da forma histórica espaço, a forma de existência histórica do espaço, afastando-se da ilusão da referência direta ao mundo.

Ao lado das duas evidências que Pêcheux (1997 [1975]) retoma de Althusser ${ }^{8}$ e reformula em sua teoria ${ }^{9}$ (a evidência do sujeito, como centro e origem de si, e a evidência da

\footnotetext{
${ }^{8}$ Althusser (1978, p. 67) reflete sobre o caráter da forma sujeito, dizendo que "a forma-sujeito, de fato, é a forma de existência histórica de qualquer indivíduo, agente das práticas sociais: pois as relações sociais de produção e de reprodução compreendem necessariamente, como parte integrante, aquilo que Lênin chama de "relações sociais | jurídico-|ideológicas", as quais, para funcionar, impõem a todo indivíduo-agente a forma de sujeito. [...] Mas o fato de que sejam necessariamente sujeitos não faz dos agentes das práticas sociais-históricas o nem os sujeito(s) da história (no sentido filosófico do termo: sujeito de). Os agentessujeitos só são ativos $n a$ história sob a determinação das relações de produção e de reprodução, e em suas formas". (grifo do autor)

9 Pêcheux (1997 [1975], p. 198) trata do funcionamento da forma-sujeito do discurso em suas práticas científica e política nas condições de produção do modo capitalista e "sob a dominância geral do jurídico", para dizer que não há "discurso científico" puro: "O único meio de esclarecer essa confusão [refere-se ao mito da neutralidade científica na produção, circulação e divulgação de conhecimento] é reconhecer que não há 'discurso da ciência' (nem mesmo, a rigor, 'discurso de uma ciência') porque todo discurso é discurso
} 
linguagem, como código que se referiria, de forma direta e transparente, às coisas do mundo, a partir de sentidos constituídos naturalmente), em suas reflexões sobre espaço, Rodríguez-Alcalá (2011) propõe-se a desenvolver uma terceira evidência, a "evidência do mundo, pela qual este se apresenta como meio natural pré-constituído, apagando-se o processo histórico de produção do espaço (político) da vida humana" (grifos da autora). Considerar, então, a evidência do mundo significa tomar o espaço não como algo neutro ou fora do sujeito e da língua, mas como "constitutivo do processo do qual resultam sujeitos e sentidos, enquanto aspecto fundamental das condições de produção do discurso" (loc. cit.). Dessa forma, permitimo-nos pensar que os processos de produção de sentidos em que se constituem sujeitos e línguas se dão em espaços produzidos historicamente, ou seja, esses espaços têm uma forma material, assim como a língua e as posições sujeitos do discurso, numa relação indissociável. Isso nos remete ao que Orlandi nos observa em relação à cidade, que o corpo do sujeito está atado ao corpo da cidade, conforme lemos anteriormente.

Pêcheux (1997 [1975] p. 129) nos lembra que as ideologias não são ideias, mas "forças materiais que constituem os indivíduos em sujeito", e que essa constituição do sujeito se imbrica com a formação do inconsciente. Portanto, ao pensar espaço em sua relação de constituição com língua e sujeito, é preciso considerar conforme Pêcheux (ibid.) que o caráter comum das duas estruturas designadas por ele como ideologia e inconsciente "é o de dissimular sua própria existência no interior mesmo de seu funcionamento, produzindo um tecido de evidências 'subjetivas', devendo entender-se este último adjetivo não como 'que afetam o sujeito', mas 'nas quais se constitui o sujeito”" (PÊCHEUX (1997 [1975], p. 152-153; grifo do autor).

Se o espaço pode ser lido nesse sentido como "observatório de processos políticos, de significação" enquanto indissociável do sujeito e da língua, e se a língua é uma das instâncias em que se materializa a ideologia, as outras duas instâncias, a autora conclui, são o sujeito e o espaço (loc. cit.). A partir daí, compreendendo a materialidade da história como contingente ("aquilo que muda ou que pode mudar") e os sujeitos como "seres históricos [...] determinados pelas condições políticas, econômicas e culturais das sociedades em que vivem, as quais darão a eles uma forma específica, ou forma sujeito, como afirma Pêcheux, retomando Althusser", é possível compreender também o espaço, em sua historicidade, se estruturando em uma forma específica: "essa forma atualmente é a cidade que, como afirma Orlandi (1999), recobre as outras e sobredetermina o social" (RODRÍGUEZ-ALCALÁ, 2011, p. 246; grifo da autora).

A partir dessa importante reflexão, permitimo-nos pensar que é possível formular sobre a forma histórica espaço de direito, considerando que: as condições de produção determinam a relação entre sujeito e língua no modo como a história os inscreve e se inscreve neles; espaço/sujeito são constitutivos simbolicamente; espaço e sujeito podem se estruturar em uma forma específica. Podemos, assim, pensar, por exemplo, que na época feudal, o espaço e o sujeito pela língua e pela história se conformaram de determinado modo diferentemente da que tomaram quando na época capitalista. Ainda apoiados nessa reflexão sobre forma histórica espaço de direito, arriscamo-nos a também pensar sobre a forma histórica espaço de direito supranacional, aquela em que se

de um sujeito - não, obviamente, no sentido behaviorista de 'comportamento discursivo de um indivíduo concreto', mas entendendo que todo discurso funciona com relação à forma-sujeito, ao passo que o processo de conhecimento é um 'processo sem sujeito'." (Grifo nosso) 
constituem/se produzem as organizações internacionais, ou seja, um grupo de espaços de direitos nacionais numa conformação supranacional.

Na esteira dessa formulação, retomamos Haroche (1992, p. 179), quando investiga a noção de determinação presente nos sistemas religiosos, posteriormente, nos jurídicos, e na gramática, para retraçar as diferentes formas-sujeito, e chegar à forma sujeito-dedireito. Nas palavras da autora,

o sujeito religioso representou, assim, uma forma sujeito diferente daquela do sujeito jurídico. Se podemos colocar na história a referência para a gênese da noção de sujeito-de-direito, também a noção de sujeito, que deriva em grande parte da ideologia, pode-se esclarecer por uma análise histórica. (HAROCHE, 1992, p. 179)

Atendo-nos à análise da noção de determinação (em sua relação com o sujeito) [...] - nós quisemos retraçar a história das diferentes "formas de sujeito" e da emergência da noção de sujeito-de-direito (id., ibid., p. 179).

Nesse ponto, retomar Miaille (2005), acreditamos, nos será bem producente, na direção da formulação sobre a forma histórica espaço de direito. Segundo esse autor, as Organizações Internacionais são consideradas como a sociedade internacional regida pelo direito internacional, e adverte que há aí nesse lugar "contradições profundas de interesses, de ideologias e de práticas. [...] mas que tudo se passa como se os interesses fossem convergentes" (MIAILLE, 2005, p. 137), pois nessa sociedade internacional os Estados Nacionais que conformam esse espaço são sempre apresentados sob a aparência jurídica, não importando se "são grandes ou pequenos, porque sempre definidos da mesma maneira" (loc. cit.). O próprio termo 'organização' é utilizado para dizer dessa sociedade internacional, mas nada se diz a respeito dos conflitos que a dividem. Fala-se, então, "de fragmentação em 'coletividades mais pequenas' nas quais a solidariedade seria mais forte, visto ser esse fenômeno que 'explicaria' as relações humanas designadamente no quadro dos Estados" (loc. cit.). Fica parecendo, pelo discurso jurídico, que não é possível haver outra forma de organização internacional que não seja a fundada por Estados-nações.

Como toda sociedade internacional foi organizada por Estados-nações poderosos ocidentais, o autor aproxima a situação da sociedade internacional à da situação interna do Estado-nação: "da mesma maneira que o sistema jurídico é a superestrutura que exprime, em geral, a força da classe dominante, assim a organização internacional corresponde, em larga medida, aos interesses dos Estados dominantes, isto é, dos Estados capitalistas" (MIAILLE, 2005, p. 138).

A partir daí, pensar a ideologia da forma histórica espaço de direito supranacional possibilita refletir sobre as organizações internacionais como espaços simbólicos supranacionais, espaços-de-direito sustentados pelo discurso jurídico internacional. Essa é uma formulação nossa pensada a partir da 'nova' ordem jurídica internacional e para pensar essa ordem, a qual se coloca pelo surgimento de espaços que se con-formam especificamente na forma histórica de Organizações Supranacionais (e não só Internacionais). Essa é uma tentativa de compreender essas 'novas' configurações da ideologia jurídica correspondentes às 'novas' configurações do capitalismo na era da mundialização, e, nessa esteira, compreender as transformações do Estado Nacional, 
enquanto espaço político e social que tem uma forma particular, que é histórica, e que muda ao longo do tempo, de acordo com as determinações sociais, políticas, econômicas, etc. de uma formação social em sua historicidade.

\section{INOVAÇÃO: FUNCIONAMENTOS DE UMA FORMA MATERIAL}

Vamos nos debruçar sobre o funcionamento da forma material inovação. Para tanto vamos observar o modo como os efeitos de sentido produzidos no discurso "sobre" e "da" inovação se atravessam e se sustentam por/em outros discursos - como, por exemplo, o da sustentabilidade, urbanismo, empreendedorismo, social, jurídico, administrativo, científico -, e como essa discursividade (se) (re)produz (em) uma forma histórica sujeito capitalista empreendedor - o sujeito da tríplice hélice.

Antes de começarmos, assinalamos dois fatos de que não trataremos nesse texto, mas que se apresentaram como marcas de regularidade no discurso da inovação: o modo como o significante 'inovação' em seu princípio de determinação se apresenta nas nominalizações "gestão de", "secretaria de", "agência de", "pró-reitoria de", etc. como pré-construído - um saber construído alhures que funciona como um "sempre-já-aí" no âmbito da formulação, ou seja, como uma evidência - sustentando cada tomada de palavra. E como no nosso arquivo de leitura ele se inscreve significando ora teoria filosófica, ora metodologia de análise/gerenciamento, ora modelo econômico, ora disciplina de currículo, ora programa de governo, ora braço de ministério público, ora projeto de plataforma de conhecimento, ora política pública, ora conhecimento propriamente dito - uma multiplicidade de sentidos, porém num movimento parafrástico, inscrevendo o diferente no mesmo.

Pensar o funcionamento do referente discursivo inovação não é nem simples nem direto. Começar por compreender a historicidade de seu processo de produção de sentidos é um modo de dar visibilidade a como o efeito de evidência funciona discursivamente.

Se pensarmos retroativamente, consideraríamos como inovação o que foi descrito como novo, criação, invenção, revolução? Se partirmos dos efeitos de sentido de inovação hoje produzidos, poderemos incorrer num anacronismo; mas não se considerarmos as condições de produção em que os sentidos são constituídos.

Há múltiplos gestos desde há muito que parecem ter deslocado sentidos em seus tempos, modificando a práxis ${ }^{10}$ linguageira, social e política, e as relações de poder que podemos significar como inovação. Dentre eles, citamos a revolução tecnológica da escrita (AUROUX (2001 [1992]), a primeira revolução tecnolinguística, que operou uma profunda transformação tanto em nossa forma de viver a linguagem, a língua e as práticas sociais, quanto no modo de produção de saberes científicos sobre elas, língua/gem e formação social.

No século XXI, podemos pensar em inovação a partir de várias definições:

\footnotetext{
${ }^{10}$ Práxis, conceito básico na filosofia marxista, remete para a transformação material da realidade; o poder que o homem tem de transformar o ambiente externo, tanto natural quanto social. Diz respeito aos instrumentos em ação que determinam a transformação das estruturas sociais. Atividade que tem a sua origem na interação entre o homem e a natureza, sendo que esta não existe por si, só em relação ao homem; a natureza só tem sentido para o homem na medida em que foi por ele modificada (BOBBIO, 1991).
} 
SD1: inovação como ideias aplicadas com êxito a resultados e processos organizacionais" ou "é a arena onde a criação e a aplicação de novas ideias são organizadas e gerenciadas formalmente. Envolve tanto preparação e objetivos deliberados quanto benefícios planejados para novas ideias que precisam ser concretizadas e implantadas. (DODGSON; GANN ${ }^{11}$ 2014, p. 24)

Esse é um dos efeitos de sentido sobre inovação em que não parece evidente o elo entre inovação e "as demandas de um mundo econômico e financeiro", por exemplo. Pode ser pensado em relação a qualquer "ideia aplicada com êxito". Mas o não-dito significa pela memória do dizer (o interdiscurso), definindo-se em função de uma formação discursiva na relação com as demais" (Orlandi, 2005, p. 49), estando, portanto, o sujeito, definido como posição constituída aí em estreita relação com essa memória, e não com qualquer uma outra. Isto é, essa posição sujeito é a mesma que significa inovação como "crucial [...] para dar conta de mercados e tecnologias em constante mudança" (id., ibid., p. 25).

SD2: introdução de novidade ou aperfeiçoamento no ambiente produtivo ou social que resulte em novos produtos, processos ou serviços (BRASIL, 2004 - Lei de Inovação $n^{\circ} 10.973$, de 2 de dezembro de 2004).

Lei que inscreve nas condições de produção a inclusão do 'novo' em ciência ou na produção social geral como uma necessidade. E, em termos discursivos, essa necessidade "cega", como nos diz Pêcheux, produz efeitos de evidência, de um já lá....

SD3: a teoria moderna do crescimento defende a hipótese de que o progresso tecnológico (inovação) é parte integrante do modelo econômico, ou seja, as bases tecnológicas da economia integram o funcionamento da economia. (SPENCE, $2011)^{12}$

Spence nos mostra, então, a formação de um ciclo da inovação, o qual relaciona numa determinada organização/direção o movimento entre produção científica e mercado (representado na figura abaixo).

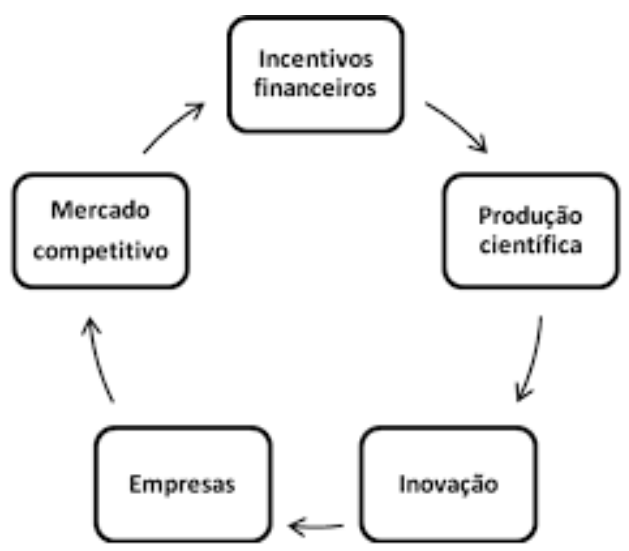

\footnotetext{
11 Mark Dodgson é diretor do Centro de Gestão da Tecnologia e da Inovação da Universidade de Queensland, Austrália e David Gann é diretor do Centro de Estudos da Inovação da Tanaka Business School, no Imperial College London e agraciado com a Ordem CBE (Order of Commander of British Empire).

${ }^{12}$ Economista americano premiado com o Nobel em 2001.
} 
Esse ciclo daria flexibilidade entre a linearidade da fase industrial e a complexidade de um novo modelo de sociedade capitalista, na qual a inovação tornou-se um dos grandes diferenciais competitivos, fazendo da constante atualização de tecnologias e processos um requisito para a sobrevivência das empresas, e instituições de ensino, pesquisa e desenvolvimento. Nesse contexto, a informação e o conhecimento passaram a ser fundamentais para o estabelecimento de estratégias eficientes das organizações modernas (MENDONÇA et alii ${ }^{13}$, 2008). Essas relações de cooperação previstas no ciclo de Spence são interpretadas como indispensáveis componentes para gerar esforços de inovação.

Nos países do hemisfério norte, considerados capitalistamente "desenvolvidos", esse ciclo adquire características quase tradicionais, enquanto que, no Brasil, essa situação ainda não foi consolidada (MENDONÇA et alii, 2008).

Ainda segundo estes autores, historicamente, a cooperação entre ciência e mercado e a inovação são eventos raros no Brasil, devido à trajetória autônoma da comunidade acadêmica, a sua dissociação das necessidades do setor produtivo, e, também, à falta de interesse e de perspectiva do setor produtivo em relação a uma possível contribuição da academia para a solução de seus problemas. Estes autores nos dizem ainda que o estabelecimento de diversas formas de cooperação já existe há séculos. Até os anos de 1980, no entanto, o estudo dessas formas de cooperação parecia restrito a cartéis. Com o aumento da concorrência decorrente da globalização e das mudanças radicais na tecnologia, particularmente em comunicação e em informação, os pesquisadores passaram a investigar outro aspecto do processo: os acordos que visam à promoção da inovação (MENDONÇA et alii, 2008).

SD4: transformar conhecimento em riqueza é o grande desafio contemporâneo para países em desenvolvimento, ou, na nova nomenclatura, emergentes como o Brasil" (VOGT; KNOBEL, 2004, p. 5). "Vivenciamos no país um esforço permanente para criar as condições de competitividade que lhe permitam participar mais efetivamente da distribuição da riqueza, hoje cada vez mais concentrada em alguns poucos países pelos efeitos da globalização da economia" (ibid., p. 4). Para tanto é preciso "produzir valor agregado" e "Ciência, Tecnologia e Inovação (C,T\&I) são indispensáveis" (ibid., p. 5). Isto é, há uma "imperiosa necessidade de o Brasil criar, com urgência, uma cultura empresarial em que o risco faça parte dos investimentos e em que os investimentos de risco constituam, como nos países ricos, fontes efetivas de financiamento da pesquisa tecnológica nas empresas (ibid., p. 4).

SD5: O impulso fundamental que põe e mantém em funcionamento a máquina capitalista procede dos novos bens de consumo, dos novos métodos de produção e de transporte, dos novos mercados e das novas formas de organização industrial todos eles elementos criados pela iniciativa capitalista [...]. A abertura de novos mercados, nacionais ou externos, e o desenvolvimento da organização da produção, desde a oficina do artesão a empresas, como a U.S. Steel, constituem exemplos do mesmo processo de mutação industrial - se me permitem essa expressão biológica que revoluciona incessantemente, a partir de dentro, a estrutura econômica, destruindo continuamente seus elementos envelhecidos e criando do mesmo modo

\footnotetext{
${ }^{13}$ Marco Aurélio A. de Mendonça é pesquisador do Instituto de Pesquisa Econômica Aplicada (Ipea); Divany G. Lima é capitão-de-fragata da Marinha do Brasil, e coordenador do Centro de Catalogação do Ministério da Defesa (MD); e Jano M. de Souza é professor de Gestão do Conhecimento Científico e da Engenharia na Coppe/UFRJ.
} 
elementos novos. Esse processo de "destruição criadora" é básico para se entender o capitalismo. É dele que se constitui o capitalismo, e a ele deve se adaptar toda empresa capitalista para sobreviver. (SCHUMPETER ${ }^{14}$, [1942] 1976, p. 82-83)

Podemos perguntar, após essa discursividade sobre inovação: a definição de inovação inova em quê? Por que é preciso haver inovação obrigatoriamente; obrigação que vem junto com necessidade?; daí a lei?; a ponto de uma política pública ser desenvolvida para isso? É evidente que a forma material inovação produza sentidos na direção do empreendedorismo capitalista?

Pensar a inovação se apresentando como o discurso do novo, significa pensar esse discurso em relação à invenção e ao discurso sobre o novo, lembrando sempre que o discurso da inovação, que se coloca como atual, diferente, "novo", atualiza redes de memória parecendo produzir uma memória outra, sentidos outros: o discurso que "aproveita fragmentos do ritual já instalado - da ideologia significante, apoiando-se em retalhos dele para instalar o novo" (ORLANDI, 2003b, p. 13).

Retomando nosso arquivo de leitura construído sobre o significante 'inovação' compreendemos que os efeitos de sentidos que circulam há algum tempo sobre inovação estão sempre ligados a mercado/demanda; comércio/finanças, custos; tecnologia; organização/estrutura, gestão, habilidades e equipe; rede/parcerias, contextos/políticas públicas, regulamentações, impostos; enfim, ligada ao retorno econômico. E é de investimento, retorno econômico, que se trata. Essa sociedade significada como sociedade de risco ${ }^{15}$ - risco ambiental, financeiro, econômico, etc. - precisa que se regue com formas materiais como (discurso da) sustentabilidade, (discurso do) empreendedorismo ("lucrar sem destruir o planeta"); e, para isso, é preciso uma nova forma de subjetivação.

\section{OBSERVAÇÕES SOBRE O SUJEITO DA INOVAÇÃO ${ }^{16} E$ SUA CONSTITUIÇÃ̃O}

Como nos diz Orlandi,

[a] mundialização, as novas tecnologias da linguagem, a mídia tal como se apresenta hoje, as guerras ideológicas contundentes, as formas sociais, o ecologismo, a xenofobia, o racismo, a relação ressignificada do Estado com o Mercado, a reorganização de uma direita letal [podem ser compreendidas, de um lado, como] as formas de existência histórica da discursividade [, e, por outro, como] as formas históricas de assujeitamento. (ORLANDI, 2012, p. 48)

\footnotetext{
${ }^{14}$ Joseph Schumpeter, economista do século passado, já escrevia a respeito da lógica da inovação, ou como ele a chamava, lógica da "destruição criadora", nos anos de 1940.Tradução nossa da citação.

${ }^{15} \mathrm{Cf}$. a reflexão de Ulrich Beck sobre a sociedade de risco mais adiante no texto.

${ }^{16}$ Nesse sentido, é interessante ler o artigo de Yurij Castelfranchi "A propriedade das invenções: história de um equilíbrio instável" (2004) em que o autor discorre sobre o conceito de patente, o que nos faz produzir relações entre forma sujeito capitalista e inovação, na medida em que coloca em jogo diferenças entre invenção e inovação, e também produz efeitos sobre a noção de propriedade do que se inventa ou se inova, discussão que ajuda a reflexão sobre a forma sujeito-empreendedor. Sugiro também a leitura da tese de doutorado de Luciana Nogueira que trata da constituição do sujeito do empreendedorismo, disponível em http://repositorio.unicamp.br/handle/REPOSIP/270660.
} 
Nessa direção, propomos pensar a forma histórica sujeito na discursividade da inovação. O sujeito se produz no efeito do sujeito empreendedor. Essa forma histórica parece ter começado a se constituir no início do século XIX, conforme podemos ler a partir da definição de 'empreendedor' a seguir (ÂNGELO, 2003).

Uma das primeiras definições da palavra empreendedor foi elaborada no início do século XIX pelo economista francês J.B. Say, como aquele que "transfere recursos econômicos de um setor de produtividade mais baixa para um setor de produtividade mais elevada e de maior rendimento". (ÂNGELO ${ }^{17}, 2003$ )

É pelo discurso da inovação que vamos ver esse sujeito afetado e interpelado como aquele que tem de estar (se) (re)(i)novando no ritmo (tempo/espaço) da inovação tecnológica, administrativa, jurídica, urbana, social. E esse, é um sujeito tripartite, composto pela universidade, pelo governo, pela empresa. Assim, no discurso da inovação ganha o nome de Tríplice Hélice ${ }^{18}$ (ETZKOWITZ; LEYDESDORFF ${ }^{19}$, 2000). Essa forma sujeito empreendedor interpela o professor, o governo e a empresa no lugar do empreendedorismo ${ }^{20}$.

Segundo o THERG-Brazil ${ }^{21}$, um grupo de pesquisa que se dedica ao estudo e desenvolvimento sobre a teoria da tríplice hélice, ou seja, sobre como o sujeito da inovação se constitui no discurso do empreendedorismo, nos diz que esse "ator ativo" ou "esferas ou hélices", ou seja, que essa forma-sujeito histórica capitalista empreendedor, como discursivamente a pensamos, está significada e sustentada

\footnotetext{
${ }^{17}$ Eduardo Bom Ângelo é economista brasileiro, e ocupou a posição de diretor-presidente da Brasilprev Seguros e Previdência até 2014.

18 Algumas correntes de pensamento discutem o desenvolvimento econômico por meio de modelos de interação formados pelo governo, setor empresarial e a infraestrutura científica e tecnológica. Uma dessas correntes é a que cria o modelo da Tríplice Hélice. Há vários tipos de modelo de tríplice hélice. Nos últimos anos, a maioria dos países tem adotado a hélice tripla em que o governo participa e incentiva o processo de inovação. Nesse modelo, a fronteira entre as instituições participantes é, em maior ou menor grau, dissolvida (ETZKOWITZ; LEYDESDORFF, 2000). Essa nova forma sujeito da hélice tripla produz efeitos de uma nova e estável infraestrutura de conhecimento, diferenciando-se do modelo tradicional de fazer ciência.

${ }^{19}$ Henry Etzkowitz e Löet Leydesdorff, ambos do campo das ciências sociais e humanas, são os fundadores da teoria da Tríplice Hélice.

20 "O empreendedorismo é hoje um fenômeno global, sobre o qual diversas instituições públicas e privadas têm investido para pesquisar e incentivar. Existe uma clara correlação entre o empreendedorismo e o crescimento econômico. Os resultados mais explícitos manifestam-se na forma de inovação, desenvolvimento tecnológico e geração de novos postos de trabalho. A riqueza gerada pelos empreendedores contribui para a melhoria da qualidade de vida da população e, não raras vezes, é reinvestida em novos empreendimentos e, de maneira indireta, nas próprias comunidades. A inovação trazida pelo empreendedorismo permite ao sistema econômico renovar-se e progredir constantemente. De acordo com Schumpeter, 'sem inovação, não há empreendedores, sem investimentos empreendedores, não há retorno de capital e o capitalismo não se propulsiona."' (ÂNGELO, 2003)

${ }^{21}$ No Brasil, mais especificamente em Niterói, há o Triple Helix Research Group (THERG-Brazil). Assim ele se define, "[o grupo] foi formalizado em agosto de 2008 para estudar as relações entre a Universidade, as Empresas e o Governo com base na abordagem da Hélice Tríplice. O núcleo de pesquisadores integrantes do grupo vem desde 1997 trabalhando em conjunto temas relacionados à gestão da inovação. O THERGBrazil está sediado no Instituto de Ciências Humanas e Sociais da Universidade Federal Fluminense - UFF, utiliza as instalações do Laboratório de Multi-Aplicações em Gestão - LAMAG e conta com o apoio da FAPERJ e do CNPq". (Disponível em: http://www.triple-helix.uff.br/sobre.html)
} 
na revisão da relação entre a Universidade e a Sociedade na qual uma segunda revolução acadêmica vem ocorrendo e a Universidade incorpora uma terceira missão, além do ensino e da pesquisa, que é ser um ator ativo do desenvolvimento econômico via geração de conhecimento científico e tecnológico e, consequente, inovação. Os grupos de pesquisa atuam como quase-firmas e interagem com os atores das demais esferas ou hélices. Como consequência emerge uma Universidade Empreendedora na qual o relacionamento entre as hélices assume diferentes configurações. Elementos e organizações de intermediação são estruturadas como as firmas spin-off, incubadoras e parques tecnológicos; escritórios de propriedade intelectual e comercialização de tecnologia; redes de conhecimento; arranjos e sistemas produtivos e inovativos locais (APLs e ASPILs); e universidades corporativas entre outros.

A dinâmica do processo de inovação situa as novas e complexas relações que se estabelecem entre as três esferas institucionais (hélices) universidade, indústria e governo como relações derivadas de transformações internas em cada uma das esferas, da influência que cada esfera tem sobre as demais, da criação de novas redes surgidas da interação entre elas, e do efeito recursivo dessas redes tanto nas espirais de onde elas emergem como na sociedade como um todo (RENAULT $\left.{ }^{22}, 2006\right)$.

A indústria é significada nessa relação da Tríplice Hélice como o locus, o governo como a fonte de relações contratuais que garantam interações estáveis e permutas, e a universidade como a fonte de novos conhecimentos e tecnologias, o princípio gerador das economias baseadas no conhecimento. A universidade empreendedora retém os papéis acadêmicos tradicionais de reprodução social e extensão do conhecimento certificado, mas os coloca num contexto mais amplo como fazendo parte do seu novo papel na promoção da inovação (ETZKOWITZ; LEYDESDORFF, 2000). Assim, a terceira missão na abordagem da Tríplice Hélice é vista como a atuação das universidades no sentido de gerar atividade econômica a partir dos resultados das atividades de pesquisa. Vamos à trindade como forma histórica de assujeitamento nessa discursividade da inovação:

a) o governo -

SD6: contribui para a inovação de muitas formas, além das políticas de inovação; [...] uma economia estável e em crescimento melhora a disposição de empresas e de indivíduos para que invistam em inovação e corram riscos (DODGSON; GANN, 2014, p. 79);

b) a organização/empresa -

SD7: enquanto enfrentam os desafios de um mundo complexo e turbulento, as organizações contemporâneas têm de responder às intermináveis demandas feitas a elas (DODGSON; GANN, 2014, p. 143).

SD8: [A inovação é fundamental para a] contínua existência [dessa forma histórica sujeito organização/empresa] já que lutam para se adaptar e evoluir para que possam

\footnotetext{
${ }^{22}$ Thiago Renault é economista, professor na UFRRJ e diretor da Agência de Inovação da Universidade Federal Fluminense.
} 
dar conta de mercados e tecnologias em constante mudança. Se querem progredir desenvolver e crescer, tornar-se mais lucrativas, eficientes, sustentáveis -, as organizações precisam implantar novas ideias com sucesso. Precisam ser continuamente inovadoras (id., ibid., p. 24-25).

c) a universidade -

SD9: um dos atores chaves na produção e disseminação do principal insumo impulsionador do desenvolvimento socioeconômico, o conhecimento (RENAULT, 2006).

Se pensarmos a chamada Sociedade do Conhecimento como o mais recente paradigma econômico, produzem-se sentidos de que as universidades são o principal espaço para a produção do conhecimento. E conhecimento nessas condições aparece ora como sinônimo de tecnologia e ora de inovação. Essa noção de conhecimento pensada dentro do conceito de "comercialização de pesquisa" é significada como commodity. A partir daí produz-se o grupo nominal "comoditização do conhecimento", em que o conhecimento passa a ser tratado como um "ativo" sobre o qual direitos de propriedade podem, e são, expressos. E, contemporaneamente, esse conceito de conhecimento inclui a discussão do modo como deve ser transferido, já que pela tríplice hélice, o conhecimento não pode mais ficar retido na universidade; é preciso que chegue ao setor produtivo e à sociedade, ou seja, que seja entregue à empresa para que ela faça circular como deve ser ( $c f$. Ciclo da inovação de Spence). Para que as transferências de tecnologia/conhecimento se processem é preciso que se institucionalize espaços responsáveis por isso. Daí a criação dos Escritórios de Inovação e Transferência de Tecnologia - os EITTs. E mais de $70 \%$ deles estão ligados às universidades públicas. $\mathrm{O}$ objetivo é o de viabilizar a transferência de conhecimentos para o setor produtivo e para a sociedade como um todo, parques tecnológicos, incubadoras de empresas e escritórios de transferência de tecnologia (RENAULT, 2006) ( $c f$. o ciclo de Spence). O que vem ao encontro do que nos dizem Mariani e Medeiros (2016) em relação à gestão de ciência hoje, uma gestão que corresponde "'a massas consideráveis de investigadores e créditos' (AUROUX, 2008) e que planifica e quantifica a produção posta como científica, (con)fundindo ofício do investigador com oficio do burocrata". Diremos, oficio do empreendedor.

É importante que esse lugar responsável pela transferência esteja

dentro de um modelo centralizado vinculado às pró-reitorias de extensão ou de pós-graduação. [...], uma das vantagens de se manter estruturas centralizadas é a possibilidade de acesso a informações de forma ampla, permitindo um acompanhamento geral de todas as potencialidades da universidade no que diz respeito a projetos de pesquisa e serviços tecnológicos. (RENAULT, 2006, p. 99)

Nessa discursividade da inovação, o significante "universidade"/"academia" é significado como um lugar de missão: sujeito nesse processo da inovação "a universidade engajada" tem uma "terceira missão". Observemos, nesse sentido, as sequências discursivas a seguir.

SD10: além de suas missões tradicionais de ensino e pesquisa, a terceira missão está relacionada ao conceito de universidade empreendedora [professor empreendedor] 
onde a instituição assume a missão de geração de atividade econômica a partir dos resultados das atividades de pesquisa. (RENAULT, 2006, p. 17)

SD11: Elas [as universidades] educarão e empregarão pessoas capazes de trabalhar de várias maneiras com pesquisa, tanto em empresas quanto no governo, construindo conexões entre diferentes partes de sistemas de inovação, incentivadas pela mobilidade de diplomados com habilidades variadas e aprimoradas com o uso da eciência. (DODGSON; GANN, 2014, p. 141)

SD12: Objetivos: O foco dos Programas PIBITI e PIBINOVA é estimular a atuação de professores da Universidade Federal Fluminense, de alunos de qualquer curso de nível superior em atividades de pesquisa, desenvolvimento e inovação, visando contribuir para a solução de problemas de mercado ou da sociedade em geral. (EDITAL PIBITI e PIBINOVA, UFF, 2015)

O sujeito que se apresenta a partir dessas condições de produção nessa fase do sistema capitalista é uma unidade de três, e é denominado como os que trabalham juntos de um modo integrado para atingir um objetivo comum, para produzir empreendedorismo.

É importante percebermos que a forma histórica sujeito empreendedor da Tríplice Hélice constitui também os sujeitos que não produzem o conhecimento/inovação, porque estes também são interpelados nesse lugar do empreendedorismo, do lucro, da oportunidade. "A inovação exige que as pessoas sejam funcionários, clientes, fornecedores, colaboradores, membros de equipe e cidadãos informados, vigilantes e responsáveis" (DODGSON; GANN, 2014, p. 150).

Não podemos nos esquecer de que o discurso da inovação se sustenta pela própria necessidade de preservar, estabilizar, e fazer repetir a ordem da verticalização, da hierarquização, estruturante e constitutiva do espaço capitalista com divisões em classes - a dos que produzem o conhecimento/inovação e a dos que o consomem - em que existimos nos subjetivando.

\section{INOVAÇÃO E EDUCAÇÃO: O FUNCIONAMENTO PARAFRÁSTICO NAS/DAS DISCURSIVIDADES}

Nesta terceira parte, vamos observar o funcionamento da intersustentação ou do atravessamento ou da paráfrase das/nas duas discursividades, a da inovação e a da educação. A essas duas, vem somar-se a discursividade da sustentabilidade. Procuramos dar visibilidade à repetição que coordena os três dizeres quando produzem interpretações sobre educação - uma não se dá sem a outra nessas condições de produção em que os dizeres da UNESCO se pretendem hegemônicos e universais, globalizados.

Entendendo com Pêcheux (1997 [1975], p. 198) que "todo discurso é discurso de um sujeito - não, obviamente, no sentido behaviorista de 'comportamento discursivo de um indivíduo concreto', mas entendendo que todo discurso funciona com relação à formasujeito"; que o sujeito é definido como posição(ções) nos discursos a partir de estreita relação com o interdiscurso, significando-se a partir de uma formação discursiva na relação com as demais; que o modo de constituição histórico-ideológica dos sujeitos e 
dos sentidos é simultâneo (ORLANDI); e que, portanto, o sentido, segundo Pêcheux (1997 [1975]), é decorrente das posições ideológicas que se produzem no e produzem o processo sócio-histórico em que "as palavras, expressões e proposições são produzidas" (p. 146); observamos, a partir disso que há articulação entre essas discursividades porque se sustentam pela repetição e pela reformulação (como relação entre substituíveis) de elementos determinados materialmente na própria estrutura do interdiscurso.

Um dizer faz atualizar certa memória porque tem historicidade, porque a história se inscreve na língua, produzindo determinados efeitos de sentido. E o 'fazer sentido' ocorre em relação a uma repetição, reprodução, ora como reprodução do mesmo (paráfrase) ora como transformação (polissemia). Sabemos - com Althusser e Pêcheux que os processos de reprodução ideológicos também funcionam como um modo de resistência, como um local no qual surge o imprevisível contingente, porque os rituais ideológicos de modo inexorável se deixam pegar pela contradição constitutiva dos processos reprodutivos. Mesmo tomando como princípio organizador do dizer uma reprodução sucessiva dos mesmos efeitos, todo enunciado é constituído por pontos de deriva que fazem com que o sentido possa se deslocar, deslizar de um para outro(s). O repetir é o retomar constituído de polissemia e de silêncio, o silêncio fundador, aquele que possibilita o dizer, pois a nossa relação com o silêncio é o que nos faz produzir sentidos $-\mathrm{o}$ silêncio em seu princípio fundante do sentido (ORLANDI).

As sequências discursivas (SD) a seguir nos ajudam a refletir sobre a questão da relação educação/inovação articulada com a relação educação/sustentabilidade a partir de textos produzidos pela UNESCO (United Nations Educational, Scientific and Cultural Organization), uma organização não só internacional mas supranacional, que sobredetermina sentidos para o modo como a relação educação/inovação deve ser significada em cada espaço nacional (Estado-membro), ou seja, mundialmente, porque a organização reconhece 195 Estados-nações independentes como seus membros e dez Estados-nações independentes como seus membros associados, ou seja, quase a totalidade dos países existentes. ${ }^{23}$

As sequências discursivas SD13, SD14 e SD15 ajudam a dar visibilidade ao processo discursivo pelas marcas em sua materialidade linguística que apontam para o modo como as determinações supranacionais votadas pela UNESCO interferem nas políticas educacionais, exigindo que estejam coordenadas com o que está na AGENDA 2030 - Transformando Nosso Mundo: A Agenda 2030 para o Desenvolvimento Sustentável - ou seja, cumprir os Objetivos de Desenvolvimento Sustentável (ODS) da ONU que são um conjunto de metas que os Estados-membros das Nações Unidas se comprometeram a cumprir até 2030. Em outras palavras, a mundialização como política necessária para pensar uma "educação de qualidade, sustentável e inovadora" - epítetos para falar de educação que se articulam e auto-inter-sustentam como co-referências (o que foi dito antes, o que é dito agora, e o que será dito depois (PÊCHEUX, 1987 [1975]) - "educação de qualidade para um futuro sustentável" e essa sustentabilidade se faz com inovação tecnológica); uma articulação entre dizeres que se sustentam pela repetição e

\footnotetext{
23 A Organização conta com 195 Estados-membros e 10 Estados-membros associados. Disponível em: https://en.unesco.org/countries/member-states. Acesso em dez. 2017. Se contarmos as regiões não reconhecidas como países pelas Nações Unidas, contaríamos 247, como, por exemplo, Palestina, Antarctica, Aruba. Disponível em: http://www.world-country.com. Acesso em dez. 2017.
} 
pela reformulação de elementos no fio do discurso materialmente determinados pela formação ideológica dominante.

SD13: 4.7 Education for sustainable development and global citizenship By 2030, ensure that all learners acquire the knowledge and skills needed to promote sustainable development, including, among others, through education for sustainable development and sustainable lifestyles, human rights, gender equality, promotion of a culture of peace and non-violence, global citizenship and appreciation of cultural diversity and of culture's contribution to sustainable development (Education transforms lives - AGENDA 2030, UNESCO, 2014, p. 17/35) (grifos nossos)

SD14: Educação para o desenvolvimento sustentável é tema de evento em São Paulo

A UNESCO no Brasil e a Secretaria Municipal de Educação de São Paulo uniramse para a realização de evento sobre Educação para Desenvolvimento Sustentável (EDS). Na ocasião, a Secretaria de Educação apresenta o projeto de EDS no novo currículo da rede municipal de ensino da capital paulista e que deve ser implantado no ano que vem.

$\mathrm{O}$ evento de lançamento da iniciativa acontece na terça-feira (15), às $15 \mathrm{~h} 30$, no Teatro João Caetano (Rua Borges Lagoa, 650, Vila Clementino, São Paulo, SP). A programação começa com a apresentação da publicação Educação para os Objetivos de Desenvolvimento Sustentável (ODS): objetivos de aprendizagem e da série de vídeos ODS para Crianças. (Disponível em https://nacoesunidas.org/educacao-para-o-desenvolvimento-sustentavel-e-tema-deevento-em-sao-paulo/. Acesso em dez. 2017) (grifos nossos)

SD15: Innovation to advance Education 2030 at Moscow UNESCO's role as a global education actor and innovative technology to achieve the new 2030 Agenda were highlighted during a special event at the Moscow International Education Fair. (Education Fair 2016. Disponível em: https://en.unesco.org/news/innovation-advance-education-2030-moscoweducation-fair-2016)

Pensar os efeitos de sentido para "sustentável" e para "educação para o desenvolvimento sustentável" junto a "todos os aprendizes"/ "all learners", ou seja, dos 205 Estados-membros não se faz sem os sentidos que hoje circulam de capitalismo empreendedor.

Observamos que entre a "UNESCO"/"UNESCO no Brasil"/"Secretaria Municipal de Educação" não há distância geográfica porque estão no mesmo espaço homogêneo da Organização Internacional, Supranacional, sob a determinação do programa mundial para "Educação para os Objetivos de Desenvolvimento Sustentável (ODS): objetivos de aprendizagem e da série de vídeos ODS para Crianças".

O desenvolvimento sustentável "é o desenvolvimento que procura satisfazer as necessidades da geração atual, sem comprometer a capacidade das gerações futuras de satisfazerem as suas próprias necessidades, significa possibilitar que as pessoas, agora e no futuro, atinjam um nível satisfatório de desenvolvimento social e econômico e de 
realização humana e cultural, fazendo, ao mesmo tempo um uso razoável dos recursos da terra e preservando as espécies e os habitats naturais" ${ }^{24}$.

A partir disso, perguntamos: esse desenvolvimento sustentável é possível tendo em vista a luta de classes existente? Essa sustentabilidade é necessária? E é necessário que o mundo seja sustentável para quem? A "educação de qualidade" é uma educação para "saber ser sustentável"? E quem deve ser educado para sustentar o mundo? Os países denominados como não ricos, os 'emergentes' e os 'pobres'? Por que o inverso não pode se dar? Educar para sustentar as futuras gerações de quais países? Dos países do Hemisfério Norte? ${ }^{25}$

A SD16 se refere aos BRICS ${ }^{26}$ e ao projeto de educação globalizado. Sabemos que em novembro de 2013, a convite da diretora-geral da UNESCO, Irina Bokova, ministros da Educação dos BRICS se reuniram na sede da UNESCO para discutir, pela primeira vez, oportunidades de cooperação na área da educação. E dessa reunião surgiu um Relatório, cujo texto é "uma contribuição para esse importante esforço de construir uma nova parceria para o progresso da educação". Esse relatório se intitula BRICS construir a educação para o futuro: Prioridades para o desenvolvimento nacional e a cooperação internacional, e apresenta um prefácio assinado pela diretora-geral da UNESCO, Irina Bokova, que constitui a SD16.

SD16: Nos últimos anos, Brasil, Federação Russa, Índia, China e África do Sul - os BRICS - transformaram o mapa mundial da educação, ao levar milhões de pessoas à escola, estabelecer centros de ensino de classe mundial, promover inovações e compartilhar experiências e conhecimentos.

Os governos dos países BRICS colocaram a educação e a capacitação no centro de suas estratégias de desenvolvimento. Em suas Constituições, todos os países BRICS têm o direito à educação instituído, e adotaram estratégias ambiciosas para concretizá-lo. Eles realizaram investimentos maciços em todos os níveis educacionais, para atender às necessidades de suas economias emergentes. Eles também têm realizado experiências com políticas inovadoras em áreas estratégicas, desde a redução das disparidades na qualidade da educação básica até o estabelecimento de instituições de ensino superior e de pesquisa mundialmente competitivas.

\footnotetext{
${ }^{24}$ Disponível em

https://www.wwf.org.br/natureza brasileira/questoes ambientais/desenvolvimento sustentavel/. Acesso em dez. 2017.

${ }^{25}$ Sabemos que os países do Hemisfério Norte possuem apenas um quinto da população do planeta, porém eles detêm quatro quintos dos rendimentos mundiais e consomem $70 \%$ da energia, $75 \%$ dos metais e $85 \%$ da produção de madeira mundial. Caso as sociedades do Hemisfério Sul copiassem os padrões das sociedades do Norte, a quantidade de combustíveis fósseis consumida atualmente aumentaria 10 vezes e a de recursos minerais, $200 \quad$ vezes. $\quad$ (Disponível em https://www.wwf.org.br/natureza brasileira/questoes ambientais/desenvolvimento sustentavel/. Acesso em dez. 2017). Nos textos das notícias que compõem nosso arquivo de leitura, observamos que dentre os países empenhados em seguir essa política da UNESCO e da OECD estão além de Finlândia, Austrália e Grécia, a Jamaica, Butão, Manitoba, Togo, República de Maurício, Quênia, Costa Rica.

${ }^{26}$ Acrônimo que se refere aos países membros fundadores (o grupo BRIC: Brasil, Rússia, Índia e China), que juntos formam um grupo político de cooperação desde 2001. Em 14 de abril de 2011, o "S" foi oficialmente adicionado à sigla BRIC para formar o BRICS, após a admissão da África do Sul. É importante que se diga que os BRICS eram responsáveis por quase 43\% da população do mundo em 2012 (UNITED NATIONS, 2012).
} 
Os BRICS têm impulsionado o progresso mundial na educação. Os cinco países têm sido importantes contribuintes para o movimento de Educação para Todos (EPT), em uma demonstração do que os governos podem alcançar por meio de investimento político e financeiro continuado na educação. A Índia, que, em 1999, abrigava uma em cada cinco crianças fora da escola primária, está perto de alcançar a meta de ter todas as crianças matriculadas. Índia e África do Sul têm expandido fortemente a educação pré-primária, com o número de matrículas tendo triplicado em apenas 14 anos, entre 1999 e 2012. O número de adultos analfabetos na China foi reduzido em 70\%, entre 1990 e 2012. Países de renda baixa, de renda média e, cada vez mais, de renda alta, têm se inspirado nas intervenções dos BRICS em diversas áreas, desde o financiamento para as pessoas pobres até estratégias inovadoras para envolver empresas no desenvolvimento de habilidades. Os BRICS também emergem como líderes em níveis mais elevados da educação. Entre 1999 e 2012, o número de estudantes no ensino superior aumentou mais de cinco vezes na China, quase triplicou no Brasil e na Índia, mais do que dobrou na África do Sul e aumentou em mais de um terço na Federação Russa. No mundo atual, mais de um em cada três estudantes vive nos países BRICS, em comparação com um em cada quatro, em 1999.

No entanto, a carência de educação ainda persiste, o que enfraquece as perspectivas de crescimento e de coesão social. Desigualdades sociais amplas e, muitas vezes, em expansão nos países BRICS refletem-se em desigualdades em todos os níveis educacionais. Famílias pobres lutam para alimentar seus filhos, o que resulta em desnutrição crônica durante os primeiros anos das crianças e causa prejuízos à sua capacidade de aprendizagem para o resto da vida. Todos os BRICS reconhecem que devem melhorar de forma significativa a qualidade da educação, se pretendem que os alunos tenham sucesso na vida e no trabalho, bem como sejam capazes de contribuir de forma positiva para a economia. (Prefácio do BRICS construir a educação para o futuro: Prioridades para o desenvolvimento nacional e a cooperação internacional - UNESCO, 2014, p. 2; grifo nosso)

Na SD16, temos a posição sujeito diretora-geral da UNESCO dizendo sobre os BRICS e a educação/inovação em seus espaços nacionais. Essa multiplicidade fica reduzida ao espaço supranacional da organização quando observa que os BRICS estabeleceram "centros de ensino de classe mundial", e que "Os cinco países têm sido importantes contribuintes para o movimento de Educação para Todos (EPT)", programa da UNESCO.

Ao tratá-los como países "emergentes" que se dedicam a investir na educação através de "políticas inovadoras" para ajudar a "transformar o mapa mundial da educação", os elogia, e os significa como os membros que cumprem com os acordos votados no espaço homogêneo da Organização, como se todos pudessem fazê-lo igualmente, tendo o mesmo desempenho que todos os outros membros. Contudo esse dizer se contradiz no momento em que mostra que "a carência de educação ainda persiste, o que enfraquece as perspectivas de crescimento e de coesão social".

Perguntamos: numa sociedade dividida como é a sociedade capitalista, em classes, como é possível nos imaginarmos, (e aqui penso nas centenas de Estados-nações, como forma-histórica espaço de direito e em todas as consequências que desse conceito podemos fazer advir), todos iguais, com as mesmas necessidades, apesar das diferenças? As riquezas estão divididas desigualmente. Os meios de produção estão também divididos igualmente. Os modos de se pensar educação/sustentabilidade/inovação são múltiplos e diversos. Silencia-se, nesse dizer sobre a educação para o "desenvolvimento sustentável", 
o político, a historicidade e a memória discursiva que fazem esses espaços nacionais ressoarem como diversos, dispersos e não controláveis. Basta retornarmos à contradição, lá se lê, "a carência de educação ainda persiste".

\section{CONSIDERAÇÕES FINAIS}

Nessa discursividade do desenvolvimento sustentável, do empreendedorismo, da inovação e sua gestão, tampona-se um furo, o real, aquilo que não cessa de se inscrever, ou seja, para o capitalismo seguir existindo é preciso ter no horizonte a ilusão do alcance da igualdade, da universalidade, da homogeneidade que apazigua, conforta e distensiona, mesmo considerando aí um certo tipo de diversidade, de diferença.

Contudo argumentamos que tratar da diversidade, diferença existente é tratar de uma divisão política, ideológica e histórica constitutiva das relações entre sujeitos/línguas/espaços; é também tratar do modo como se observa essa divisão, interrogando-nos: o que se faz com ela? Como nos sustentarmos nela? Como fazê-la sustentar as práticas discursivas de modo a que ela (a diferença) não se apague; e, ao mesmo tempo, se constitua na mistura?

É preciso olhar para a diferença como uma relação em que $(\mathrm{A})$ e $(\mathrm{B})$ estejam à mesma distância, num movimento não regulado, não uniforme, não hierárquico. Conforme Orlandi (1990),

na diferença, um é diferente do outro. Estão na mesma distância e é no movimento entre um e outro que podemos apreender as suas relações. Não é um o modelo e o outro a cópia. Não se trata de considerar um primeiro e um segundo (hierarquizada e reguladamente), nem tampouco dois iguais e separados claramente entre si, em si. (ORLANDI, 1990, p. 41)

\section{REFERÊNCIAS}

ALTHUSSER, L. Resposta a John Lewis. Rio de Janeiro: Edições Graal, 1978.

ÂNGELO, E. B. Empreendedorismo: a revolução do novo Brasil. Revista da Faap de Economia \& Relações Internacionais. São Paulo, vol. 1, n. 2, p. 37-48, jan. 2003. Disponível em: http://www.faap.br/revista_faap/rel_internacionais/empreendedorismo.htm. Acesso em dez. 2015.

AUROUX, S. A revolução tecnológica da gramatização. Campinas: Ed. da Unicamp, 2001 [1992].

BOBBIO, N.; MATEUCCI, N.; PASQUINO, G. Dicionário de Política. $3^{\text {a }}$ ed. Brasília: Ed. da UnB; Linha Gráfica Editora, 1991. [Obra em 2 v.] 
BRANCO, L.K.A. CASTELLO. A língua em além-mar: sentidos à deriva - o discurso da CPLP sobre língua portuguesa. Tese. Doutorado em Linguística, Campinas, Universidade Estadual de Campinas, Instituto de Estudos da Linguagem, 2013.

Inovação: significante em movimento. Em: MARIANI, B. (Org.). Enciclopédia audiovisual virtual de termos, conceitos e pesquisas em Análise do Discurso e áreas afins: investigação, inovação, divulgação. Rio de Janeiro: Makunaima, 2016. Disponível em http://www.edicoesmakunaima.com.br/catalogo/5-enciclopedia/22-enciclopediavirtual-ad-investigacao-inovacao-divulgacao.

BRASIL. Lei $n^{\circ} 10.973$, de 2 de dezembro de 2004. Dispõe sobre incentivos à inovação e à pesquisa científica e tecnológica e dá outras providências. Disponível em http://www.planalto.gov.br/ccivil 03/_Ato2004-2006/2004/lei/L10.973.htm. Acesso em 30 set. 2015.

CASTELFRANCHI, Y. A propriedade das invenções: história de um equilíbrio instável. ComCiência, SBPC/Labjor, 2004. Disponível em: http://www.comciencia.br/reportagens/2004/08/03 impr.shtml. Acesso em 22 nov. 2015.

DODGSON, M.; GANN, D. Inovação. Trad. Bras. Porto Alegre: L\&PM, 2014.

ETZKOWITZ, H.; LEYDESDORFF, L. The dynamics of innovation: from National Systems and "Mode 2"' to a Triple Helix of university-industry-government relations. Research Policy, $n^{\circ}$ 29, 2000.

FERRY, L. A inovação destruidora: ensaio sobre a lógica das sociedades modernas. Rio de Janeiro: Objetiva, 2015.

GUIMARÃES, E. Semântica do Acontecimento: um estudo enunciativo da designação. Campinas: Pontes, 2005 [2002].

HARDT, M.; NEGRI, A. Império. Trad. Bras. 9ª ed. Rio de Janeiro: Record, 2010.

HAROCHE, C. Fazer dizer, querer dizer. São Paulo: HUCITEC, 1992.

HENRY, P. Sentido, sujeito, origem. Em: ORLANDI, E.P. (Org.). Discurso fundador: a formação do país e a construção da identidade nacional. $3^{\mathrm{a}}$ ed. Campinas: Pontes, 2003.

HERDER, Johann Gottfried. Sur la nouvelle littérature allemande. Fragments, Lettres sur l'avancement de l'humanité. In: CAUSSAT, P.; ADAMSKI, D.; CREPON, M. La langue source de la nation. Messianismes séculiers en Europe centrale et orientale (du XVIIIe au XXe siècle). Lièges: Mardaga, 2003 [1766]. p. 77-106.

LEFEBVRE, H. La production de l'espace. Preface. Revue internationale de recherches et de synthèses sociologiques - L'homme et la société, Sociologie de la connaissance marxisme et anthropologie, $\mathrm{n}^{\mathrm{o}}$ 31-32, p. 15-32, 1974. Disponível em: http://www.persee.fr/doc/homso_0018-4306_1974_num_31_1_1855. Acesso em nov. 2014. 
MARIANI, B. Arquivo e língua nacional: percursos de pesquisa. Em: MEDEIROS, V. G.; TEDESCO, M.T. (Orgs.). Travessia nos estudos de língua portuguesa: homenagem a Evanildo Bechara e Olmar Guterres, 2010. p. 81-99.

MARIANI, B. (Org.). Enciclopédia audiovisual virtual de termos, conceitos e pesquisas em Análise do Discurso e áreas afins: investigação, inovação, divulgação. Rio de Janeiro: Makunaima, 2016. Disponível em: http://www.edicoesmakunaima.com.br/catalogo/5-enciclopedia/22-enciclopedia-virtualad-investigacao-inovacao-divulgacao.

MARIANI, B.; MEDEIROS, V. Disciplinarização dos Estudos em Análise de Discurso. Gragoatá, Universidade Federal Fluminense, nº 34, Niterói, EdUFF, 2014.

MENDONÇA, M.A. de; LIMA, D.G.; SOUZA, J.M. de. Cooperação entre o Ministério da Defesa e COPPE/UFRJ: uma abordagem baseada no modelo triple helix III. Em: DE NIGRI, J.A.; KUBOTA, L.C. (Eds.). Políticas de incentivo à inovação tecnológica. Instituto de Pesquisa Econômica Aplicada (IPEA), Brasília, 2008. Disponível em: http://www.ipea.gov.br/portal/images/stories/PDFs/livros/capitulo15 27.pdf. Acesso em 18 Set 2015.

MIAILLE, M. Introdução crítica ao direito. Lisboa: Editorial Estampa, 2005.

ORLANDI, E. Análise de discurso e contemporaneidade científica. Em: Discurso em análise: sujeito, sentido, ideologia. Campinas: Pontes, 2012. p. 37-54.

ORLANDI, E. (Org.). Discurso e políticas públicas urbanas: a fabricação do consenso. Campinas: Ed. RG, 2010.

ORLANDI, E. Discurso e texto: formulação e circulação de sentidos. $2^{\mathrm{a}}$. ed. Campinas: Pontes, 2005.

. Cidade dos Sentidos. Campinas: Pontes, 2004.

Análise de discurso: princípios e procedimentos. $6^{\mathrm{a}}$ ed. Campinas: Pontes, $2003 \mathrm{a}$.

Discurso fundador: a formação do país e a construção da identidade nacional. Campinas: Pontes, 2003b.

. Nota ao leitor. Em: PÊCHEUX, M. O discurso: estrutura ou acontecimento. Trad. Bras. Campinas: Pontes, 2002.

(Org.). Cidade atravessada. Os sentidos públicos no espaço urbano. Campinas, Pontes, 2001.

ORLANDI, E. Terra à vista: discurso do confronto: velho e novo mundo. São Paulo: Cortez, 1990.

PÊCHEUX, M. Semântica e discurso: uma crítica à afirmação do óbvio. Trad. Bras. Campinas: Editora da Unicamp, 1997 [1975]. 
RBPG [Revista Brasileira de Pós-Graduação], vol. 10, nº 20, Brasília, Capes, julho, 2013.

RENAULT, T. O desenvolvimento socioeconômico como terceira missão da universidade: elementos para estudo do caso brasileiro. Dissertação. Mestrado em Engenharia de Produção, Universidade Federal Fluminense, Área de Concentração: Tecnologia, Inovação e Trabalho, Niterói, 2006.

RODRÍGUEZ-ALCALÁ, C.M ${ }^{\mathrm{a}}$. Discurso e cidade: a linguagem e a construção da evidência do mundo. Em: BRANCO, L.K.A.C.; SANTOS, G.L. dos; RODRIGUES, E.A. (Orgs.). Análise do Discurso no Brasil. Pensando o Impensado Sempre. Uma Homenagem a Eni Orlandi. Campinas: RG Editora, 2011. p. 243-258.

Em torno de observações para uma teoria geral das ideologias de Thomas Herbert. Estudos da língua(gem), n. 1 [Michel Pêcheux e a análise de discurso, organizado por M. da C. FONSECA-SILVA e E.J. SANTOS], Vitória da Conquista, UESB, 2005.

SCHUMPETER, J. Capitalism, socialism, and democracy. Introd. de Richard Swedberg. London; New York: Routiledge [Taylor \& Francis e-Library, 1942] 2003.

SPENCE, M. Os desafios do futuro da economia: o crescimento econômico mundial nos países emergentes e desenvolvidos. Trad. Bras. Rio de Janeiro: Elsevier, 2011.

TÖNNIES, Ferdinand. Comunidad y asociación. El comunismo y el socialismo como formas de vida social. Barcelona: Ediciones Península, 1979 [1887].

TRIPLE HELIX RESEARCH GROUP. Disponível em: http://www.triplehelix.uff.br/sobre.html. Acesso em 14 fev. 2016.

UNESCO. Resolution adopted by the General Assembly on 25 September 2015. General Assembly. Seventieth session. Agenda, items 15 and 116, 21 October 2015.

UNESCO. BRICS - construir a educação para o futuro: Prioridades para o desenvolvimento nacional e a cooperação internacional. ISBN 978-92-3-700002-1 (UNESCO Paris); ISBN 978-85-7652-194-5 (UNESCO Brasília).

UNESCO. Education transforms lives - AGENDA 2030 [Sustainable Development Goals].

UNITED NATIONS. Educação para o desenvolvimento sustentável é tema de evento em São Paulo. Disponível em: https://nacoesunidas.org/educacao-para-o-desenvolvimentosustentavel-e-tema-de-evento-em-sao-paulo/. Acesso em set. 2017.

VOGT, C; KNOBEL, M. Ciência, tecnologia e inovação no Brasil. ComCiência, SBPC/Labjor, 2004. Disponível em http://www.comciencia.br/reportagens/2004/08/01.shtml. Acesso em 22 nov. 2015. 
Artigo recebido em: fevereiro de 2018.

Aprovado e revisado em: abril de 2018.

Publicado em: maio de 2018.

\section{Para citar este texto:}

BRANCO, Luíza Kátia Andrade Castello. Inovar para (não) mudar: língua, organização internacional, educação. Entremeios [Revista de Estudos do Discurso, ISSN 2179-3514, on-line, www.entremeios.inf.br], Seção Estudos, Programa de Pós-Graduação em Ciências da Linguagem (PPGCL), Universidade do Vale do Sapucaí (UNIVÁS), Pouso Alegre (MG), vol. 16, p. 193-218, jan. - jun. 2018.

DOI: http://dx.doi.org/10.20337/ISSN2179-3514revistaENTREMEIOSvol16pagina193a218 